\title{
나노 $\mathrm{SiC}$ 입자의 형상에 따른 탄소섬유 강화 에폭시 복합재료의 기계적 및 계면 물성 변화 관찰
}

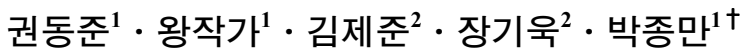 \\ ${ }^{1}$ 경상대학교 나노신소재융합공학과, 공학연구원, ${ }^{2}$ (주)티비카본 복합신소재연구소 \\ (2013년 5월 22일 접수, 2013년 6월 8일 수정, 2013년 6월 11일 채택)
}

\section{Improvement of Mechanical and Interfacial Properties of Carbon Fiber/Epoxy Composites by Adding Nano SiC Fillers}

\author{
Dong-Jun Kwon', Zuo-Jia Wang ${ }^{1}$, Je-Jun Kim², Key-Wook Jang ${ }^{2}$, and Joung-Man Park ${ }^{1 \dagger}$ \\ ${ }^{I}$ Department of Materials Engineering and Conversion Technology, Engineering Research Institute, \\ Gyeongsang National University, Gyeongnam 660-701, Korea \\ ${ }^{2}$ Advanced Composites Materials R\&D Center, 164 Soju, Gyeognam 626-280, Korea \\ (Received May 22, 2013; Revised June 8, 2013; Accepted June 11, 2013)
}

\begin{abstract}
요 약: $\mathrm{SiC}$ 나노입자를 이용하여 에폭시 복합재료를 제조할 수 있다. $\mathrm{SiC}$ 형상에 따른 영향으로 복 합재료의 계면 물성이 변화된다. $\mathrm{SiC}$ 의 형상에 따른 계면 상태의 변화를 관찰하기 위해 베타 형태, 위스커 형태의 $\mathrm{SiC}$ 나노입자를 사용하였다. 나노입자에 대한 분산도를 평가하기 위해 커패시턴스를 이용한 분산도 평가방법을 활용하였다. FE-SEM을 이용하여 $\mathrm{SiC}$ 나노입자의 활용에 따른 나노복합 재료의 파단면을 관찰하여, 그 강화 효과를 비교 분석하였다. 탄소섬유와 $\mathrm{SiC}$ 나노입자가 함유된 에 폭시를 이용한 복합재료에 계면 물성을 비교하기 위해 층간전단강도 평가법과 계면전단강도 평가법 을 이용하였다. 복합재료의 계면 물성을 강화하기 위해서는 베타 형태의 $\mathrm{SiC}$ 나노입자를 활용할 경 우가 위스커 입자를 이용한 경우보다 높은 계면 강도를 나타냈다.
\end{abstract}

\begin{abstract}
Epoxy matrix based composites were fabricated by adding SiC nano fillers. The interfacial properties of composites were varied with different shapes of $\mathrm{SiC}$ nano fillers. To investigate the shape effects on the interfacial properties, beta and whisker type $\mathrm{SiC}$ nano fillers were used for this evaluation. The dispersion states of nano SiC-epoxy nanocomposites were evaluated by capacitance measurements. FE-SEM was used to observe the fracture surface of different structures of SiC-epoxy nanocomposites and to investigate for reinforcement effect. Interfacial properties between carbon fiber and SiC-epoxy nanocomposites were also evaluated by ILSS (interlaminar shear strength) and IFSS (interfacial shear strength) tests. The interfacial adhesion of beta type nanocomposites was better than whisker type.
\end{abstract}

Keywords: SiC nano filler, Nanocomposites, ILSS, IFSS, stress transfer

\section{1. 서 론}

$\mathrm{SiC}$ 나노입자의 경우 구조재료에 활용되는 가장일반 적인 무기재료 중 하나이다. 공업적으로 에치슨 공정 에 의해 제조되며 공유 결합이 높은 물질이기 때문에 기계적 물성이 높고 고온에 안정적인 물성을 가지는

\footnotetext{
${ }^{\dagger}$ Corresponding author: Joung-Man Park (jmpark@gnu.ac.kr)
}

강화재이다[1-4].

$\mathrm{SiC}$ 나노입자의 제조 방법의 차이에 의해 결정구조 를 이루는 상이 다르게 제조될 수 있다. 강화재의 형상 에 따른 물성의 차이를 볼 수 있듯이 $\mathrm{SiC}$ 나노입자의 형상에 따른 강도 비교를 진행해 볼 수 있다. 일반적으 로 나노입자의 고른 분산이 이루어질 경우 가장 높은 강도 및 계면 강화적인 면에서 효과를 볼 수 있다. 하 지만 나노입자의 경우 분산의 문제가 크게 발생되기 
때문에 최적 입자 크기가 존재한다[5-7]. 위스커 형태 의 강화재의 경우 막대 형의 강화재이기 때문에 기지 재료와의 계면 접착력이 용이하다면 높은 기계적 강도 를 보유할 수 있다. 하지만 막대형의 형상이기 때문에 재료의 배열 및 강화재 간의 응집이 문제가 된다[8].

에폭시에 $\mathrm{SiC}$ 나노입자를 강화재로 활용하여 최적의 탄소섬유 강화 $\mathrm{SiC} /$ 에폭시 복합재료를 제조하여 낚시 대용 프리프레그를 제조하는 것을 목적으로 연구하였 다. 낚시대를 위한 프리프레그를 제조하기 위해서는 $\mathrm{SiC} /$ 에폭시 수지와 탄소섬유 사이의 강한 결합을 유도 하는 것이 중요하다[9,10]. 이때 사용되는 $\mathrm{SiC}$ 나노입 자의 크기와 형상에 따른 영향을 분석하기 위해 본 연 구를 진행하였다.

$\mathrm{SiC}$ 나노입자 형상은 베타 형태, 위스커 형태 두 종 류에 대해서 강화재로의 효과를 비교 분석하였다. 에 폭시 수지는 일반적인 비스페놀 $\mathrm{A}$ 형 에폭시에 산무수 물계 경화제를 활용하여 기지재료로 활용하였다. 일반 적으로 $\mathrm{SiC} /$ 에폭시 수지에 대한 나노복합재료를 통해 수지 자체의 물성 개선 정도를 분석하였다. FE-SEM을 이용하여 나노입자의 상태를 분석하고, $\mathrm{SiC} /$ 에폭시 재 료의 인장 후 파단면을 관찰하였다. 재료의 강성도와 파단면 결과를 비교하여 최적 $\mathrm{SiC}$ 나노입자 강화재 효 과를 확인하였다. 탄소섬유와 $\mathrm{SiC} /$ 에폭시 수지 간의 계 면을 분석하기 위해 층간전단강도(ILSS)와 계면전단강 도(IFSS)를 활용하여 최적의 $\mathrm{SiC}$ 나노입자 강화 효과 를 평가하였다.

\section{2. 실 험}

\section{1. 재료}

Figure 1은 사용한 $\mathrm{SiC}$ 나노입자에 대한 형상을 확인 한 FE-SEM 결과이다. Figure 1(a), (b)는 베타 형태의 2 종류 $\mathrm{SiC}$ 나노입자이다. $15 \mathrm{~nm}$ 직경을 가진 입자와 55 $\mathrm{nm}$ 직경을 가진 나노입자(Nanostructure \& Amorphous Co., 미국) 상태이다. Figure 1(c), (d), (e)는 위스커 형 태의 $\mathrm{SiC}$ 나노입자 3종류이다. 두 종류의 $\mathrm{SiC}$ 나노입 자(Advanced Composites materials Co., 미국)는 직경이 $0.65 \mu \mathrm{m}$ 이며, 길이가 $11 \mu \mathrm{m}$ 인 위스커 형태이다. 두 재 료의 차이는 표면처리의 유무이다. Figure 1(d) 재료는 아무런 처리를 하지 않은 $\mathrm{SiC}$ 나노입자이다. Figure 1(e) 나노입자는 아민기를 표면처리한 나노입자이다. 마지막 하나의 Figure 1(c) 위스커 타입 $\mathrm{SiC}$ 입자 (Nanostructure \& Amorphous Co., 미국)는 직경과 길이 가 불균일한 막대 형태의 나노입자이다.

탄소섬유(미쯔비씨, TR $50 \mathrm{~S} 15 \mathrm{~L}$, 일본)를 강화재로 활용하였으며, 수지는 비스페놀 A계 에폭시(YD-114, (주)국도화학)와 산무수물계 경화재(KBH-1089, (주)국

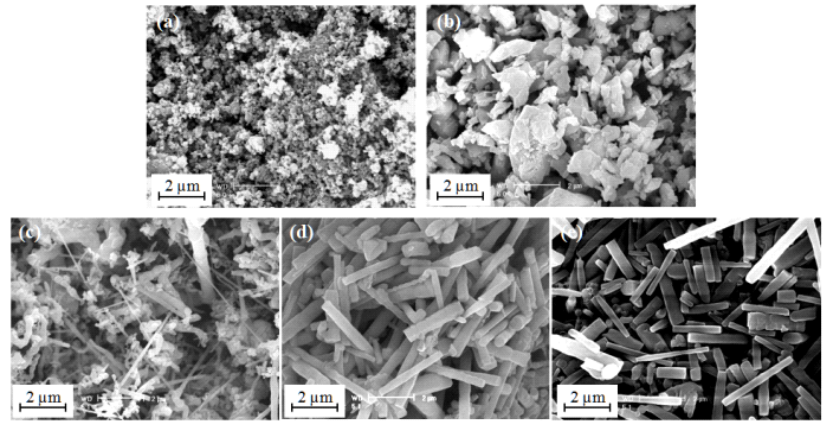

Figure 1. FE-SEM of the $\mathrm{SiC}$ nano fillers; (a) $15 \mathrm{~nm} \mathrm{SiC}$ beta type, (b) $55 \mathrm{~nm} \mathrm{SiC}$ beta type, (c) whisker $\mathrm{SiC}$ whisker type, (d) $\mathrm{TB} 050 \mathrm{SiC}$ whisker, (e) $\mathrm{TB} 110 \mathrm{SiC}$ whisker.

도화학)를 $1: 1$ 로 반응시켜 기지재료로 활용하였다.

\section{2. 실험 방법}

2.2.1. $\mathrm{SiC}$ 나노입자의 형상에 따른 $\mathrm{SiC} /$ 에폭시 복합재 료의 기계적 물성평가

$\mathrm{SiC}$ 나노입자를 에폭시 수지에 함침시키기 위해 초 음파처리 과정을 $3 \mathrm{~h}$ 가지고 $1 \mathrm{wt} \%$ 의 함량으로 $\mathrm{SiC} /$ 에 폭시 복합재료를 제조하였다. $\mathrm{SiC}$ 나노입자의 형상에 따른 강화효과의 차이를 분석하기 위해 기계적 물성을 평가하였다. 인장, 굴곡, Izod 충격 실험을 각각 진행하 였으며, 실험 방법은 ASTM 방법을 기준으로 평가하였 다[11-13]. 압축 실험은 브로트만 압축 시편을 이용하 여 실험을 진행하였다[14]. 브로트만 시편의 장점은 시 편의 중앙 부분에 압력을 가해줄 때 시편의 중앙부에 전단력이 최소로 가해지기 때문에 압축력에 대한 평가 를 용이하게 할 수 있는 장점이 있다.

2.2.2. $\mathrm{SiC}$ 분산도 및 강도와 상관성 비교를 위한 Capacitance 측정

커패시턴스는 무기물 재료로 이루어진 축전기에 대 한 전하량 및 전기용량을 측정하기 위한 전기 용어이 다. 아래의 간단한 수식 (1)과 같이 커패시턴스 $\mathrm{C}$ 와 전 압 $\mathrm{V}$ 의 곱으로 한 구간의 전하량 $\mathrm{Q}$ 결과를 확인할 수 있다[15].

$$
Q=C \times V
$$

전기가 통하지 않는 에폭시 수지를 축전기라고 생각 해 볼 수 있다. 에폭시 수지 내부에 $\mathrm{SiC}$ 나노입자가 함 유되어 있어도 부도체 상태이다. 에폭시만의 전기용량 을 측정할 수 있으며, $\mathrm{SiC} /$ 에폭시 복합재료의 경우, $\mathrm{SiC}$ 의 보유 전하량과 에폭시의 전하량이 합해져서 더 높은 커패시턴스(전기용량)를 의미한다. 이러한 전하량 적 접근은 본 연구실에서 처음 시도하고 있으며, 에폭 
시 내부에 $\mathrm{SiC}$ 나노입자의 분산상태가 용이할수록 높은 커패시턴스 결과가, 분산상태가 나쁠수록 커패시턴스 결과가 낮았다. 즉 커패시턴스 결과를 이용하여 무기물 의 분산도를 평가할 수 있다는 것이다. 본 연구에서는 무기물 입자의 분산도 뿐만아니라 인장 강도와 커패시 턴스 측정 결과를 비교하여 상관성을 유추해 보았다.

2.2.3. 계면전단강도와 충간전단강도 평가

탄소섬유 강화 $\mathrm{SiC} /$ 에폭시 복합재료 제조를 위하여 계면 강도를 확인할 기계적 평가방법을 진행하였다. 층간전단강도 결과를 확인하기 위해 탄소섬유가 40 $\mathrm{vol} \%$ 의 비중을 차지하도록 하며, $\mathrm{SiC} /$ 에폭시 복합재료 를 기지로 사용함으로써 계면 강도 평가 시편을 제조 하였다. 거시적인 평가를 위하여 short beam 실험법을 바탕으로 층간전단강도 결과를 확인하였다. $\mathrm{SiC}$ 형상 에 따른 층간계면강도를 관찰하였다[16,17]. 미시적인 계면 강도 결과를 확인하기 위해 계면전단강도 평가를 실행하였다. 탄소섬유 단일 한 가닥에 $\mathrm{SiC} /$ 에폭시 복합 재료를 묻혀 물방울 형상을 이루게 한다[18]. 이후 마 이크로 바이스를 이용하여 물방울 모양으로 이루어진 섬유 표면에 경화된 수지를 아래로 당기면서 수지와 섬유의 계면에서 발생된 최고 전단력 결과와 수지가 함침되어 있던 면적으로 나누어 계면전단강도를 계산 하였다. 실험을 위해 만능시험기(LR $10 \mathrm{~K}$, 로이드, 미 국)로 $0.5 \mathrm{~mm} / \mathrm{min}$ 으로 작동하였다.

\section{3. 결과 및 토의}

\section{1. $\mathrm{SiC}$ 나노입자의 형상에 따른 $\mathrm{SiC} /$ 에폭시 복합재료 의 인장강도 및 커패시턴스 분석}

Figure 2는 $\mathrm{SiC}$ 나노입자의 형상에 따른 강화 효과 차이를 분석하기 위해, $\mathrm{SiC} /$ 에폭시 복합재료의 인장 실 험한 결과이다. $\mathrm{SiC}$ 나노입자의 형상에 따라 강화 효 과의 차이가 발생하였다. 최적의 강화 효과는 $55 \mathrm{~nm}$ 직경의 $\mathrm{SiC}$ 나노입자를 사용할 경우, 최대 $90 \mathrm{MPa}$ 에 가까운 인장강도와 $3.8 \%$ 정도의 연신율을 확인하였다. 하지만 베타 형태의 $15 \mathrm{~nm}$ 직경의 $\mathrm{SiC}$ 소재는 $55 \mathrm{~nm}$ 직경 $\mathrm{SiC}$ 나노입자에 비해 강화 효과가 적었다. 인장 강도에 대한 결과 편차도 크게 발생되었다. 이러한 문 제는 재료 내부에 강화재의 분산도가 중요한 영향을 미친다는 것이다. 모든 종류의 강화재 분산 처리 과정 을 동일하게 처리하였기 때문에 $15 \mathrm{~nm}$ 직경 $\mathrm{SiC}$ 나노 입자의 분산성은 균일하지 못하였다. 베타 형태와 위 스커 형태의 강화 효과 경향은 다소 차이가 존재하였 다. 아민 표면처리를 하지 않은 TB 050 소재와 아민 표면처리를 한 TB 110 소재의 강도 증가 효과에 있어 서 차이는 적었다. 오히려 아민 표면처리를 하지 않은

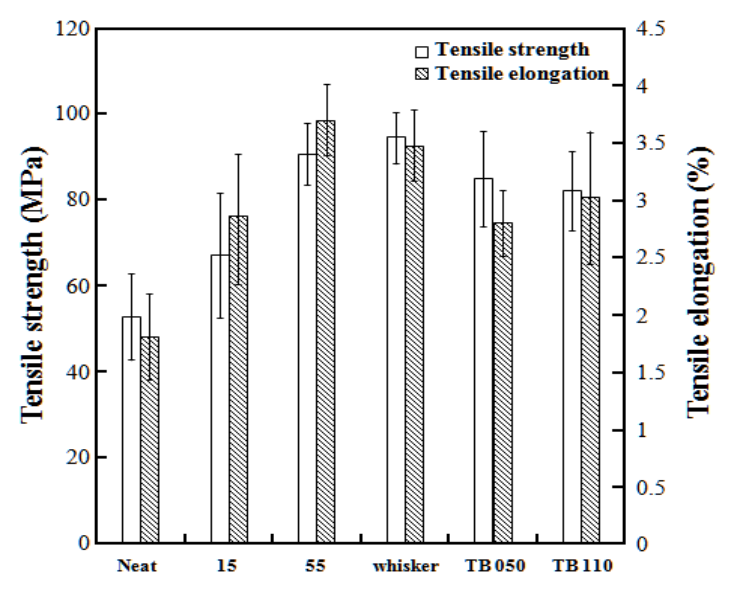

Type of SiC composites

Figure 2. Tensile strength and elongation of SiC/epoxy nanocomposites with different shape of $\mathrm{SiC}$ nano filler.

$\mathrm{TB} 050$ 강화재를 사용한 경우가 더 높은 물성을 확인 하였다. 이는 $\mathrm{SiC}$ 나노입자의 표면처리를 하는데 있어 서 $\mathrm{SiC}$ 나노입자의 표면처리가 균일하게 되지 못한 점 또한 문제가 될 수 있다. 또한 아민기와 에폭시간 계면 반응성이 용이하지 못한 결과가 발생되어 인장강도에 대한 편차가 크게 발생되었다. 위스커 $\mathrm{SiC}$ 나노입자의 경우 최고의 인장강도를 나타냈지만, 신율 증가는 베 타 형태 $\mathrm{SiC}$ 나노입자의 강화 효과보다 낮았다. 이는 비록 불규칙하고 상이지만, 베타 형태의 소재의 경우 정육면체와 같이 6 개의 방향으로 균일한 화학적 결합 을 유도할 수 있다. 하지만 위스커 형태는 막대 형태이 기 때문에 막대의 길이에 해당하는 면에서만 주로 화 학적 결합을 이루게 되어 방향성을 띄는 강화 효과 차 이가 발생된다. 이러한 형상학적 문제에 있어서 불균 일하게 수지 내부에 배치되는 나노입자의 분산 결과는 강화 효과와 차이를 유발한다. 이러한 결과로 위스커 타입의 $\mathrm{SiC}$ 나노입자보다, 베타 형태의 나노입자가 강 화 효과에 더 용이하다는 것을 확인하였다.

Figure 3 의 결과는 $2 \mathrm{~cm}$ 간격에서 $\mathrm{SiC} /$ 에폭시 복합재 료의 수지에 구리선을 삽입하여 측정한 커패시턴스 결 과이다. 이 결과를 비교하여 볼 경우 Figure 2 의 인장 강도와 유사한 경향이 있었다. 식 (1)을 바탕으로 할 때 커패시턴스와 전하량은 비례관계이다. LCR 미터로 측정한 커패시턴스 결과와 인장강도간의 상관관계를 확인하였다. 일차적으로 커패시턴스의 측정 결과를 이 용하여, $\mathrm{SiC}$ 나노입자 분산 상태는 비교해 볼 수 있다. 에폭시의 경우도 발생되는 일정량의 편차가 존재하였 다. 하지만 $\mathrm{SiC}$ 나노입자를 함유할 경우 커패시턴스 결과와 결과에 대한 편차 크기가 증가된다. 분산이 균 일 할수록 높은 커패시턴스 결과와 편차의 폭이 낮았 으며, 분산이 불균일할수록 커패시턴스의 결과가 낮고, 


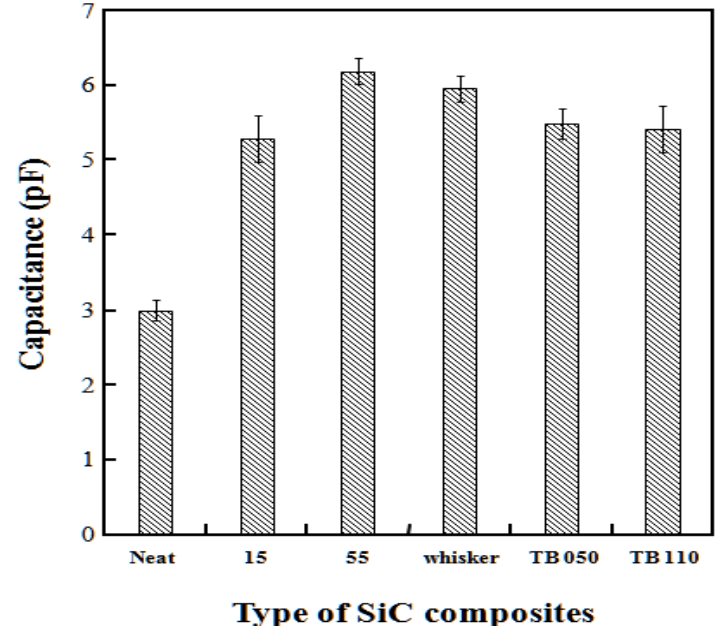

Figure 3. Evaluation of capacitance of SiC/epoxy nanocomposites with different shape of $\mathrm{SiC}$ nano filler.
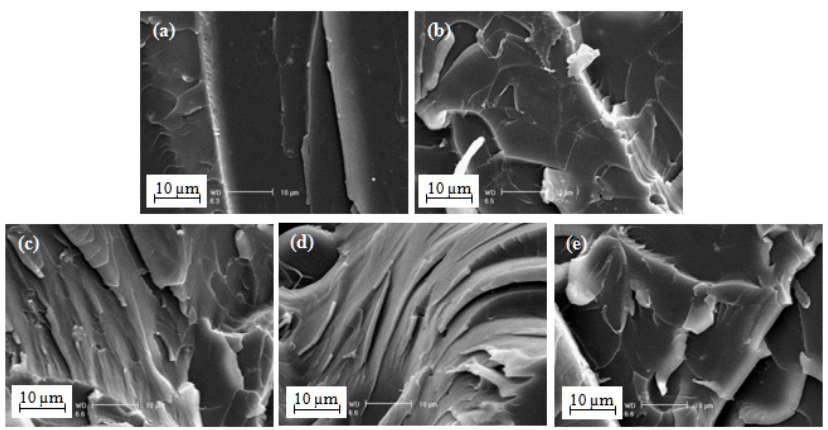

Figure 4. Fracture surface of $\mathrm{SiC} /$ epoxy nanocomposites; (a) $15 \mathrm{~nm} \mathrm{SiC}$ beta type, (b) $55 \mathrm{~nm} \mathrm{SiC}$ beta type, (c) whisker SiC whisker type, (d) TB $050 \mathrm{SiC}$ whisker, (e) TB 110 $\mathrm{SiC}$ whisker.

편차가 크게 발생되었다. $15 \mathrm{~nm}$ 직경 $\mathrm{SiC}$ 나노입자의 경우 편차의 폭이 컸다. 이는 수지 내부에 $15 \mathrm{~nm} \mathrm{SiC}$ 나노입자가 불균일하게 분산되어 있다는 것을 의미한 다. 나노입자 분산을 위해서는 최적의 분산 방법이 필 요함을 부수적으로 확인할 수 있었다. 또한 재료의 인 장 강도 결과와 커패시턴스 결과는 유사한 상관관계 가 있었으며, $55 \mathrm{~nm}$ 직경 $\mathrm{SiC}$ 나노입자의 경우 가장 큰 커패시턴스 결과를 얻었고 편차도 낮았다. 용이한 분산상태와 강화 효과를 발생시키는 $\mathrm{SiC}$ 나노입자는 $55 \mathrm{~nm}$ 직경 $\mathrm{SiC}$ 나노입자의 경우임을 예상할 수 있었다.

Figure 4 는 $\mathrm{SiC}$ /에폭시 복합재료에 대한 파단면을 관 찰한 결과이다. 결과를 통해 확인할 수 있는 점은 위스 커 타입의 나노복합재료의 경우 파단면에 결이 존재하 였다. 하지만 파단면에 대해서 미세한 craze들의 발생 이 확인되기 보다는 미세 crack이 쉽게 관찰되었다. 하 지만 베타 타입의 $\mathrm{SiC}$ 나노입자 활용 복합재료의 경우 미세 craze의 발생이 관찰되었다. Crack은 미세 균열의

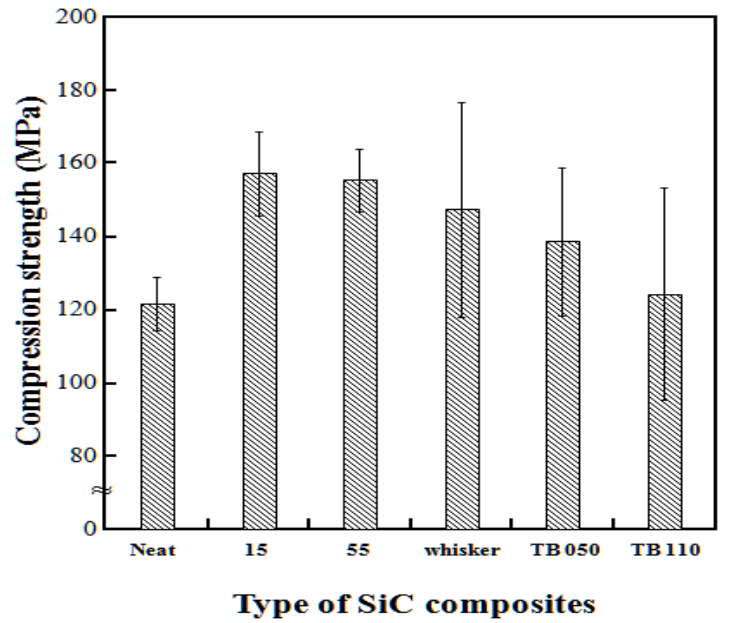

Figure 5. Compression strength of SiC/epoxy nanocomposites with different shape of $\mathrm{SiC}$ nano filler.

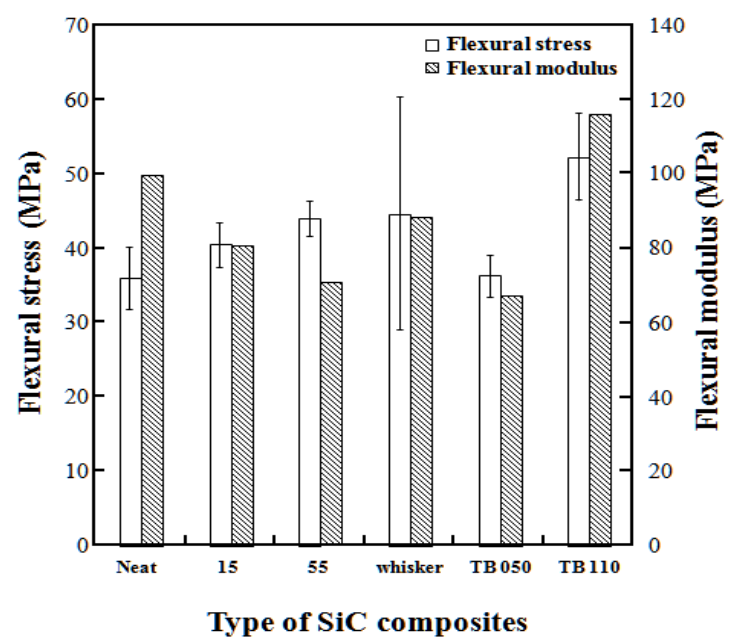

Figure 6. Flexural stress and modulus of SiC/epoxy nanocomposites with different shape of $\mathrm{SiC}$ nano filler.

시작점이지만, crack이 발생되기 전에 craze들의 발생이 성장하여 crack이 되는 것이다. Craze의 발생 정도가 많다는 점은 균열이 발생되는 것을 최대한 줄이기 위 해 재료가 파단면에서 파괴가 지연되었다는 것을 의미 한다. 인장강도에 대한 결과와 연관지어 생각해볼 경 우 $55 \mathrm{~nm}$ 의 직경을 가진 $\mathrm{SiC}$ 나노입자가 최적의 강화 재라 할 수 있다.

\section{2. $\mathrm{SiC} /$ 에폭시 복합재료의 압축, 굴곡, 충격물성 분석}

Figure 5는 압축 실험에 대한 결과를 정리한 결과이 다. 압축 실험의 결과는 베타 형태와 위스커 형태의 $\mathrm{SiC}$ 나노입자의 강화 효과 차이를 관찰하였다. 베타 형태 $\mathrm{SiC}$ 나노입자를 활용할 경우 복합재료의 기계적 물성은 안정적이고, 높은 압축강도를 확보하였다. 하지 


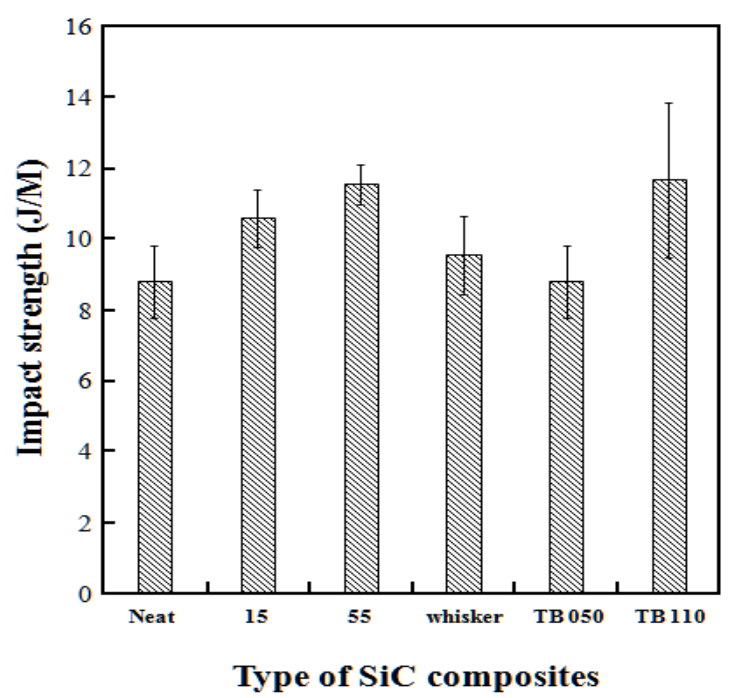

Figure 7. Impact strength of SiC/epoxy nanocomposites with different shape of $\mathrm{SiC}$ nano filler.

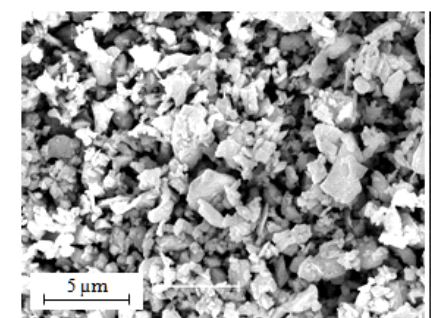

(a)

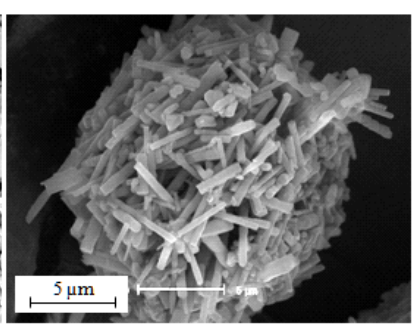

(b)
Figure 8. Investigation of $\mathrm{SiC}$ nano filler; (a) $55 \mathrm{~nm} \mathrm{SiC}$ and (b) TB 110.

만 위스커 형태의 $\mathrm{SiC}$ 나노입자는 압축 강도의 강화 정도가 낮았다. 결과에 대한 편차가 크기 때문에 압축 력에 의한 $\mathrm{SiC}$ 나노입자 배열성이 문제가 되어 위스커 형태의 강화재는 불안정한 강화 물성 결과를 가지는 것으로 확인하였다.

Figure 6은 3점 굴곡 실험을 통해 확인한 굴곡강도 및 굴곡강성도에 대한 결과를 정리한 결과이다. 고탄 성을 추구하는 낚시대용 수지이기 때문에 굴곡강성도 가 낮아야 효과적이라 말할 수 있다. 잘 휘어져야, 휨 안정성을 가지기 때문이다. $55 \mathrm{~nm}$ 직경 $\mathrm{SiC}$ 나노입자 의 활용이 효과적인 수지 굴곡 물성을 가졌다.

마지막으로 Figure 7은 Izod 충격 실험법을 이용하여 재료의 충격 강도를 비교한 결과이다. TB 110 소재의 강도 증가가 유독 높았다. 이전의 인장, 압축, 굴곡 실 험에서는 아민기를 표면처리한 것에 대한 효과가 거의 없었다. 하지만 충격에 대한 안정성을 강화시키는데 있어서 아민기의 효과가 존재함을 확인하였다.

이러한 물리적 평가 결과를 바탕으로 일반적으로 기 계적 물성 강화를 위해서는 위스커 형태의 강화재보다

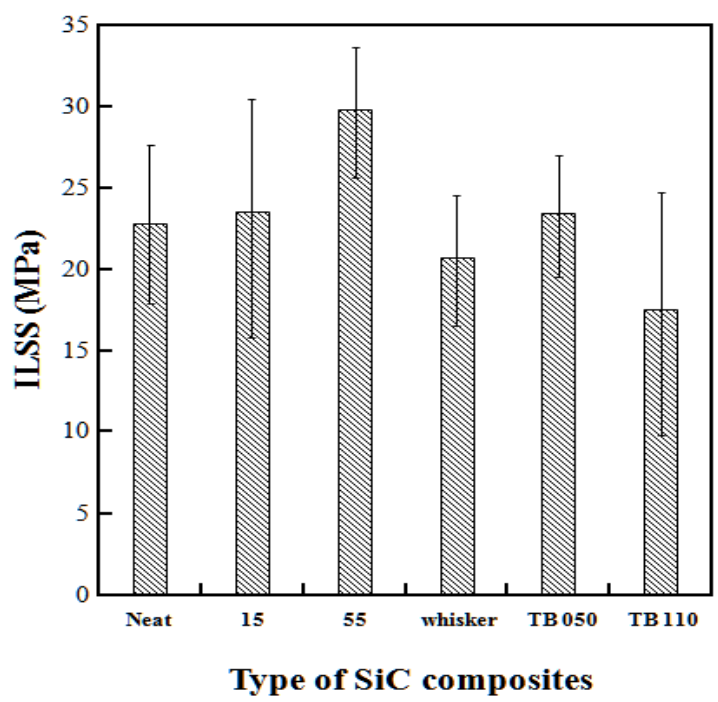

Figure 9. Interlaminar shear strength of SiC/epoxy nanocomposites with different shape of $\mathrm{SiC}$ nano filler.

베타 형태의 나노입자가 효과적인 강화 효과를 나타낸 다고 말할 수 있었다.

Figure 8 은 $\mathrm{SiC}$ 나노입자의 응집력에 대해서 관찰하 기 위해 비교한 FE-SEM 결과이다. Figure 8(a)의 베타 형태의 $\mathrm{SiC}$ 나노입자는 입자와 입자 간의 응집이 관찰 되지 않는다. 다만 입자의 크기가 불균일하다는 점이 문제 될 수 있다. 하지만 Figure 8(b)와 같은 경우 아민 기로 $\mathrm{SiC}$ 나노입자의 표면처리를 한 위스커 형태이다. 이는 재료 간 응집이 크게 발생된 것을 관찰 할 수 있 었다. 아민 처리에 의해 재료 간의 응집이 발생된 것으 로 생각할 수도 있지만, 막대형 구조와 $\mathrm{SiC}$ 나노입자 간의 응집력에 의해 재료가 하나의 덩어리화되어 있다 는 점은 최적의 분산 방법이 아니면 최적의 강도를 발 휘하기 어려운 강화재임을 예상할 수 있게 한다.

\section{3. 탄소섬유 강화 $\mathrm{SiC} /$ 에폭시 복합재료의 계면 강도 분석}

Figures 9 와 10 의 결과는 거시적, 미시적 계면 물성 평가방법의 일환으로 사용되는 층간전단강도 결과와 계면전단강도 결과를 재료별로 정리한 결과이다. 이 결과를 통해 확인할 수 있는 점은 탄소섬유와 $\mathrm{SiC} /$ 에 폭시 복합재료를 이용할 경우 계면 물성이 증가될 수 도 있지만 계면 물성이 감소될 수도 있음을 확인 할 수 있었다. 베타 형태 $\mathrm{SiC}$ 나노입자의 경우 계면 물성 이 증가되었다. 비록 물성의 증가 정도는 소폭이지만, 위스커 형태의 $\mathrm{SiC}$ 나노입자를 활용하는 것에 비해 계 면 강도 강화 효과는 존재하였다.

계면전단강도의 결과와 층간전단강도의 결과에 대해 서 큰 폭의 차이가 존재하는데 이런 점에 대해서는 미 


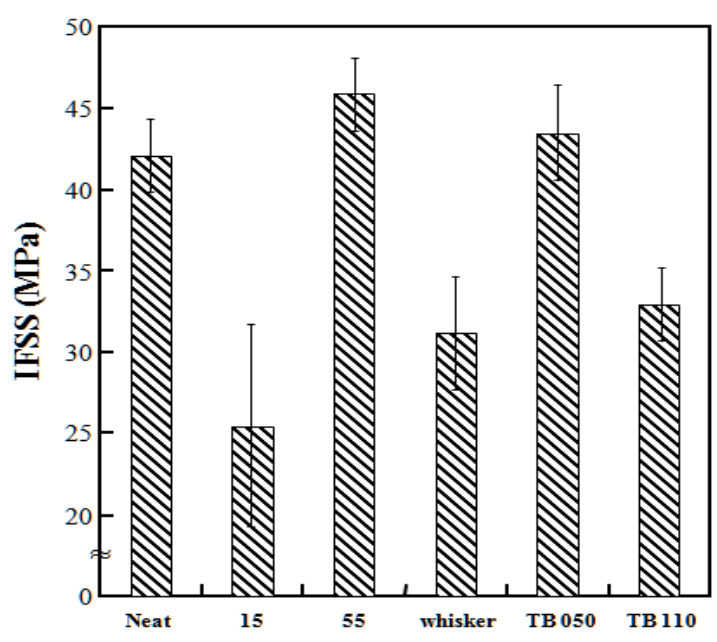

Type of SiC composites

Figure 10. Interfacial shear strength of SiC/epoxy nanocomposites with different shape of $\mathrm{SiC}$ nano filler.

시적 평가와 거시적 평가의 차이에 의한 결과라 예상 할 수 있다. 그리고 $15 \mathrm{~nm}$ 직경 $\mathrm{SiC}$ 나노입자를 이용 할 경우 계면 강도의 차이가 크게 발생된다는 점에서 $\mathrm{SiC}$ 나노입자의 분산 문제가 계면 강도 안정화에 큰 영향을 준다고 예상할 수 있다.

Figure 11의 모델은 $\mathrm{SiC}$ 형상에 따른 복합재료 제조 시 나노입자의 퍼짐정도를 비교한 그림이다. 이 결과 를 통해 섬유와 섬유 사이에 $\mathrm{SiC}$ 나노입자의 젖음성이 중요한데, 베타 형태 $\mathrm{SiC}$ 나노입자가 효과적으로 섬유 와 섬유 사이에 퍼지는 것을 예측할 수 있다. 위스커 형태의 $\mathrm{SiC}$ 나노입자는 큰 형상비에 의해 섬유와 섬유 사이에 수지가 퍼지지 못하여 효과적인 계면 강도 강 화를 유발 확인할 수 없었다.

\section{4. 결 론}

고탄성 낚시대용 프리프레그를 제조하기 위해 $\mathrm{SiC}$ 나노입자의 최적 형상을 확인하기 위한 기계적 평가 실험을 진행하였다. $\mathrm{SiC}$ 형상은 크게 위스커 형태와 베타 형태로 존재하며, 길이 및 표면처리에 따른 영향 들을 복합적으로 비교하였다. $\mathrm{SiC} /$ 에폭시 복합재료에 대한 수지적 물성 강화 효과를 관찰하기 위해 인장 실 험을 진행하고 $\mathrm{FE}-\mathrm{SEM}$ 을 이용한 파단면을 관찰하였 다. Crack의 전파 및 craze의 발생여부를 비교하고, 커 패시턴스 측정을 통한 인장 강도와 커패시턴스 결과가 비례관계임을 확인하였다. 기계적 물성 평가로 인장뿐 만 아니라 압축, 굴곡, 충격 실험을 진행을 하였다. 기 계적 물성 평가의 결과로 최적의 $\mathrm{SiC}$ 형상은 베타 형 태임을 확인할 수 있었다. $\mathrm{SiC}$ 나노입자의 표면처리

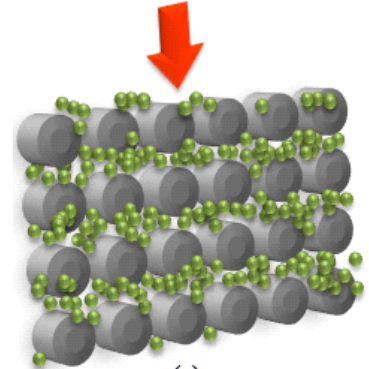

(a)

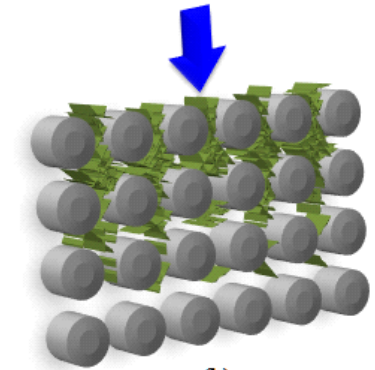

(b)
- Sphere type Carbon fiber Whisker type

Figure 11. Model of SiC/epoxy nanocomposites with different shape of $\mathrm{SiC}$ nano filler.

효과는 충격 강도 증가에 영향이 있었으며, 위스커 타 입의 형상적 문제와 입자 간 응집력이 높은 문제로 인 해 베타 형태가 최적임을 증명하였다. 탄소섬유를 이 용하여 복합재료를 제조하여, 섬유와 기지 간 계면 물 성에 $\mathrm{SiC}$ 나노입자의 영향을 비교하였다. 층간전단강 도와 계면전단강도 평가를 진행하였다. 미시적 계면 평가인 계면전단강도 결과가 층간전단강도 결과보다 더 크게 측정되었으며, 최적의 $\mathrm{SiC}$ 나노입자는 $55 \mathrm{~nm}$ 직경의 베타 형태 소재임을 확인하였다. 위스커 형태 의 나노입자를 활용할 경우 계면 강도에 증가가 발생 되지 않는 이유는 섬유와 섬유 사이로 $\mathrm{SiC} /$ 에폭시 복 합재료 수지가 용이하게 스며들지 못하기 때문에 발생 되는 계면 강도의 저하 결과를 확인하였다.

\section{감사의 글}

본 연구는 지식경제부가 지원하는 동남권 광역경제 권선도산업 $\mathrm{R} \& \mathrm{D}$ 연구과제로 수행된 것이며, 지원에 대해 진심으로 감사드립니다.

\section{참 고 문 헌}

1. T. Zhou, X. Wang, G. U. Mingyuan, and L. Xiaoheng, Polymer, 49, 4666 (2008).

2. H. Alamri and I. M. Low, Mater. Des., 42, 214 (2012).

3. M. Vlastimil, L. Yafei, J. Long, L. Huang, G. S. Martynkova, and V. Toma, Tribol. Int., 43, 144 (2010).

4. J. Magnant, L. Maillé, R. Pailler, and J. C. Ichard, J. European Ceram. Soc., 32, 4497 (2012).

5. J. Xiaolong, L. Gang, L. Baiyang, L. Yuming, G. Yang, and X. Yang, Compos. Part A, 48, 101 (2013).

6. J. M. Park, Z. J. Wang, J. H. Jang, N. J. R. Gnida- 
koung, W. I. Lee, J. G. Park, and K. L. DeVries, Compos. Part A, 40, 1722 (2009).

7. S. J. Park and Y. S. Jang, J. Colloid Interface Sci., 237, 91 (2001).

8. M. H. Choi, B. H. Jeon, and I. J. Chung, Polymer, 41, 3243 (2000).

9. S. S. Kim, D. C. Park, and D. G. Lee, Compos. Struct., 66, 359 (2004).

10. Z. J. Wang, N. J. R. Gnidakoung, M. S. Kim, J. M. Park, and M. G. Um, J. Adhesion and Interface, 10, 162 (2009).

11. L. C. S. Nunes, F. W. R. Dias, and H. S. da Costa Mattos, Polym. Test, 30, 791(2011).

12. R. Rajkiran and D. R. Paul, Polymer, 52, 5595 (2011).

13. J. Gangchang, Q. Shengru, D. Shuangming, H. Dong, and L. Mei, Mater. Sci. Eng. A, 483, 123 (2008).

14. T. Schüller, W. Beckert, B. Lauke, C. Ageorges, and K. Friedrich, Compos. Part A, 31, 661(2000).

15. D. T. Horn, Basic Electronics Thoery with Projects and Experiments, $4^{\text {th }}$ ed, McGraw-Hill, New York, U.S.A.

16. M. S. Hong, K. M. Bae, W. K. Choi, H. S. Lee, S. J. Park, K. H. An, and B. J. Kim, Chem. Eng. J., 23, 313 (2012).

17. G. Jung, C. W. Nah, M. K. Seo, J. H. Byun, K. H. Lee, and S. J. Park, Polymer (Korea), 36, 612 (2012).

18. Z. J. Wang, D. J. Kwon, G. Y. Gu, J. K. Park, W. I. Lee, and J. M. Park, J. Adhesion and Interface, 11, 149 (2010). 